\title{
Optimisation of the co-combustion of meat-bone meal and sewage sludge in terms of the quality produced ashes used as substitute of phosphorites
}

\author{
Zygmunt Kowalski $^{1} \cdot$ Marcin Banach $^{2} \cdot$ Agnieszka Makara $^{2}$ (D)
}

Received: 25 March 2020 / Accepted: 27 September 2020 / Published online: 14 October 2020

(C) The Author(s) 2020

\begin{abstract}
To obtain a high-quality phosphorus raw material comparable in quality to the best phosphorites used in the fertiliser industry, an analysis was carried out to determine the optimal mass proportions of a meat-bone meal and sewage sludge mixture to be used in a cocombustion process. The ashes obtained contained hydroxyapatite that could be considered a high-quality substitute for phosphorites, with an average $\mathrm{P}_{2} \mathrm{O}_{5}$ content of $33.5 \%$. These ashes do not contain fluorine compounds, cadmium content is at trace levels and they do not contain the radioactive compounds that are present in trace amounts in all phosphates. The developed process is an example of a production complex using cleaner technologies and circular economy principles on a microeconomic scale.
\end{abstract}

Keywords Meat-bone meal $\cdot$ Sewage sludge $\cdot$ Thermal utilisation $\cdot$ Ash quality $\cdot$ Phosphorite

\section{Introduction}

In the European Union, $18 \mathrm{Mt} /$ year of meat waste is generated and is mainly processed into meat-bone meal (MBM). The EU produces 4.5 Mt/year of MBM, used typically as biofuel (Hiromi Ariyaratne et al. 2015; Gulyurtlu et al. 2005) and mineral-organic fertilisers (Möller 2015; Lucid et al. 2013). Studies (Nogalska and Zalewska 2013; Černý et al. 2012) indicate that MBM is a valuable source of phosphorus for grain crops and, in particular, silage maize and increased maize productivity.

Thermal treatment of waste from the meat industry in a large-scale rotary kiln was presented by Staroń et al. (2017). The main results of research into combustion, pyrolysis and gasification of MBM (Cascarosa et al. 2012) showed that the products could be used as fertiliser (solid product) and as fuel (gas and liquid products). The work aimed at reviewing the

Responsible Editor: Philippe Garrigues

Agnieszka Makara

amak@chemia.pk.edu.pl

1 Mineral and Energy Economy Research Institute Polish Academy of Sciences, Wybickiego 7, 31-261 Krakow, Poland

2 Faculty of Chemical Engineering and Technology, Cracow University of Technology, Warszawska 24, 31-155 Krakow, Poland most significant studies into the potential application of the products obtained in these thermochemical processes that contain hydroxyapatite. Thermal decomposition of MBM was investigated by Conesa et al. (2003). Characteristics of industrial and laboratory MBM ashes and their potential applications were presented by Coutand et al. (2008). Hu et al. (2017) dealt with hydroxyapatite and its ferroelectric properties that may be interesting for biological/biomedical applications.

Under the European project COPOWER, three cocombustion scenarios ( $\mathrm{Sc}$ ) were studied: $\mathrm{Sc} 0-$ combustion of coal, Sc1 - combustion of coal + sewage sludge (SS) + MBM and $\mathrm{Sc} 2-$ coal $+\mathrm{SS}+$ wood pellet (WP). From the environmental point of view, $\mathrm{Sc} 0$ was the worst scenario and $\mathrm{Sc} 1$ the best, due mainly to the reduction in GHG emission, eutrophication chemical species and ozone-depleting gases. From the socioeconomic point of view, $\mathrm{Sc} 0$ was the worst scenario $\mathrm{Sc} 1$ the best, due to the lowest cost of electricity production and negative cost of avoided emissions (Morais et al. 2011).

In Hiromi Ariyaratne et al. (2015), MBM and coal combustion in a rotary cement kiln were simulated and the results compared. The equilibrium temperature of the MBM combustion products was $300 \mathrm{~K}$ lower than those of coal combustion, due mainly to the higher air demand, higher ash and moisture content and poor char burnout (83\%) of MBM. Fluidised bed co-combustion of MBM with coal were also investigated by Fryda et al. (2006) and Gulyurtlu et al. (2005). 
The granulation of meat and bone meal, straw and SS and incineration of granulated product were investigated by Kowalski et al. (2012). The incineration of MBM/feather mixtures was tested by Staron et al. (2015). The thermal conversion of granules from feathers, MBM and poultry litter to ash with fertilising properties were proposed by Staron et al. (2017a). The work by Heikkinen et al. (2008) described computational fluid dynamics CFD simulation and experimental validation of co-combustion of chicken litter and MBM with pulverised coal in a flow reactor. According to Wzorek (2015), fuels based on the combined use of MBM and SS fulfil the requirements and may be applied as a substitute for coal in clinker cement burning.

The evaluation of the four alternative SS management strategies (Bertanza et al. 2016) led to the following preference order: agricultural use $\gg$ incineration $>$ cement kiln $\cong$ wet oxidation. The assessments of the leading SS disposal (volume reduction) and energy recovery routes such as incineration, pyrolysis and gasification were made by Raheem et al. (2018). The thermal treatment of SS and the characteristics of ashes from its incineration were presented briefly by Tarko (2016).

These solutions are an example of the application in industrial practice of circular economy (CE) systems, emphasising the possibility of using to the greatest possible extent the value contained in materials (Asif et al. 2016). According to the CE, combustion for energy recovery is also a useful option. In this way, the product life cycle value chain retains the highest possible value and quality as long as possible and is also as energy efficient as it can be (Ghisellini et al. 2016; Bilitewsky 2012).

For general use in the fertiliser industry, phosphate rock or its concentrates preferably have levels of $30 \% \mathrm{P}_{2} \mathrm{O}_{5}$, reasonable amounts of $\mathrm{CaCO}_{3}(5 \%)$ and $<4 \%$ combined iron and aluminium oxides (Filippelli 2011; Blatt and Tracy 1996). Worldwide, the resources of high-grade ore are declining, and the beneficiation of lower-grade ores occurs through washing, screening, de-liming, magnetic separation or flotation (Hogan 2011; Zapata and Roy 2004).

The basic criterion regarding the quality of phosphate rock used in the production of phosphoric acid is content (Eq. 1) $\mathrm{P}_{2} \mathrm{O}_{5}$ or BPL (bone phosphate of lime; Becker 1989):

$\mathrm{BPL}=2.1852 \cdot \mathrm{P}_{2} \mathrm{O}_{5}$

Phosphate rock with a content of $33-39 \% \mathrm{P}_{2} \mathrm{O}_{5}(72-85$ $\mathrm{BPL})$ is considered to be of high quality. Medium-quality rock contains 30-33\% $\mathrm{P}_{2} \mathrm{O}_{5}$ (65-72 BPL) and low-quality 26-30\% $\mathrm{P}_{2} \mathrm{O}_{5}$ (57-65 BPL) (International Fertilizer Development Center 1998; Podolak 2017).

For processing of phosphorites into phosphoric(V) acid and NP or NPK fertilisers, the sum of aluminium, iron and magnesium oxides (Becker 1989) is of particular importance. The high value of this sum can lead to poor chemical properties of superphosphates, problems during the fertiliser production process and drying of products made from phosphoric acid obtained from such phosphates. For processing of phosphorites into phosphoric(V) acid and NP or NPK fertilisers, the sum of aluminium, iron and magnesium impurities determined by the Minor Element Ratio (MER) index (Becker 1989; BAT 2000) is used (Eq. 2):

$\mathrm{MER}=100 \times\left(\sum\left(\mathrm{Al}_{2} \mathrm{O}_{3}, \mathrm{Fe}_{2} \mathrm{O}_{3}, \mathrm{MgO}\right)\right) / \mathrm{P}_{2} \mathrm{O}_{5}(\%)$

If the $\sum\left(\mathrm{Al}_{2} \mathrm{O}_{3}, \mathrm{Fe}_{2} \mathrm{O}_{3}, \mathrm{MgO}\right)$ content increases $>3 \%$ by mass, there are problems associated with precipitation during concentration, cooling and storage of phosphoric acid. High concentrations of iron and aluminium during storage may cause acid compounds containing digestible forms of $\mathrm{P}_{2} \mathrm{O}_{5}$ to convert into compounds with the non-digestible form of $\mathrm{P}_{2} \mathrm{O}_{5}$. Typically, the acceptable level of impurities in $\mathrm{H}_{3} \mathrm{PO}_{4}$ used to produce fertilisers is given by Eq. 3 (BAT 2000; Podolak 2017):

$0.02 \leq\left(\mathrm{Fe}_{2} \mathrm{O}_{3}+\mathrm{Al}_{2} \mathrm{O}_{3}\right) / \mathrm{P}_{2} \mathrm{O}_{5} \leq 0.08$

Table 1 presents composition of phosphorite ores used for production of phosphoric acid and phosphorus fertilisers, including types of impurities important in these processes, calculated from Podolak (2017).

The BPL value of phosphorites could be considered rather as medium-quality raw materials, with $\mathrm{P}_{2} \mathrm{O}_{5}$ in the range 28.9-33.8\%, a $\left(\mathrm{Fe}_{2} \mathrm{O}_{3}+\mathrm{Al}_{2} \mathrm{O}_{3}\right) / \mathrm{P}_{2} \mathrm{O}_{5}$ value in range $0.02-$ 0.16 and MER index in range $3.0-16.8 \%$. All phosphorites also contain typically (\%): 3.5-4.0 F, 48.0-51.0 CaO, 2.4-5.0 $\mathrm{SiO}_{2}$ and 0.32-2.9 $\mathrm{SO}_{3}$ (Becker 1989).

Co-combustion of MBM and SS for energy recovery from these wastes and the use of the obtained ash containing hydroxyapatite as alternative raw material for the production of phosphorus compounds have been proposed (Stokłosa et al. 2019; Kowalski and Makara 2017). The goal of the research was to determine the optimal mass proportions of cocombusted MBM and SS that would allow obtaining ash with a quality comparable or better than that in phosphorite ores used in Poland for the production of phosphoric acid.

\section{Materials and methods}

\section{Characteristic of ash after combustion of MBM/SS mixture}

MBM and SS were come from Farmutil Inc. the biggest Polish MBM producer, having own large MBM wastewater 
Table 1 Content of $\mathrm{P}_{2} \mathrm{O}_{5}$ and impurities in phosphorites (used as expected parameters for ashes from co-combustion of MBM and SS)

\begin{tabular}{|c|c|c|c|c|c|c|c|c|}
\hline \multirow[t]{2}{*}{ Phosphorite type } & \multicolumn{8}{|c|}{ Content $(\%)$ or ratio $(\%)$} \\
\hline & $\mathrm{P}_{2} \mathrm{O}_{5}$ & $\mathrm{Al}_{2} \mathrm{O}_{3}$ & $\mathrm{Fe}_{2} \mathrm{O}_{3}$ & $\left(\mathrm{Fe}_{2} \mathrm{O}_{3}+\mathrm{Al}_{2} \mathrm{O}_{3}\right) / \mathrm{P}_{2} \mathrm{O}_{5}$ & $\mathrm{MgO}$ & $\mathrm{MER}^{\mathrm{a}}$ & $\mathrm{Cd}(\mathrm{ppm})$ & $X_{\mathrm{Cd}}\left(\mathrm{mg} \mathrm{Cd} / \mathrm{kg} \mathrm{P}_{2} \mathrm{O}_{5}\right)$ \\
\hline Morocco-Togo & 33.8 & 0.888 & 0.973 & 0.06 & 0.23 & 6.2 & 37 & 109 \\
\hline Tunisia-Jordan & 29.8 & 0.423 & 0.287 & 0.02 & 0.33 & 3.5 & 13 & 44 \\
\hline Morocco-Syria & 29.7 & 0.348 & 0.171 & 0.02 & 0.39 & 3.1 & 11 & 37 \\
\hline Tunisia-Syria & 28.9 & 0.357 & 0.189 & 0.02 & 0.40 & 3.3 & 13 & 45 \\
\hline Tunisia-Syria & 28.9 & 0.427 & 0.197 & 0.02 & 0.44 & 3.7 & 17 & 59 \\
\hline Syria & 30.0 & 0.23 & 0.17 & 0.01 & 0.45 & 2.8 & 7 & 23 \\
\hline Tunisia & 29.1 & 0.47 & 0.36 & 0.03 & 0.65 & 5.1 & 33 & 113 \\
\hline Algiers & 29.9 & 0.32 & 0.44 & 0.03 & 0.95 & 5.7 & 16 & 54 \\
\hline Togo & 33.5 & 1.08 & 1.33 & 0.07 & 0.17 & 7.7 & 49 & 146 \\
\hline Morocco & 31.6 & 0.30 & 0.20 & 0.02 & 0.45 & 3.0 & 16 & 51 \\
\hline Egypt & 28.9 & 0.49 & 1.70 & 0.08 & 0.30 & 8.6 & 9.5 & 33 \\
\hline Senegal Matam & 32.3 & 1.19 & 0.80 & 0.06 & 0.38 & 7.3 & 11 & 34 \\
\hline Senegal Lam-Lam & 33.3 & 3.59 & 1.62 & 0.16 & 0.38 & 16.8 & 52 & 156 \\
\hline
\end{tabular}

${ }^{\mathrm{a}}$ Minor element ratio, MER $=100 \times\left(\sum\left(\mathrm{Al}_{2} \mathrm{O}_{3}, \mathrm{Fe}_{2} \mathrm{O}_{3}, \mathrm{MgO}\right)\right) / \mathrm{P}_{2} \mathrm{O}_{5}(\%)$

treatment unit. MBM combustion unit (capacity $4 \mathrm{t} / \mathrm{h}$ ) started in 2019. The co-combustion of MBM and sewage sludge dry mass (SSDM) was carried out on experimental facility. The schematic diagram of the MBM thermal processing is shown in Fig. 1 (Kowalski and Makara 2017; Stokłosa et al. 2017).
Calcining of MBM in a rotary kiln includes complete incineration of organic part of the MBM in a two-stage process carried out with at least $20 \%$ excess air compared to the stoichiometric amount necessary for the complete oxidation of the organic materials. In a co-current rotary kiln, thermal
Fig. 1 Flow-sheet of the MBM/

$\mathrm{SS}$ co-combustion unit

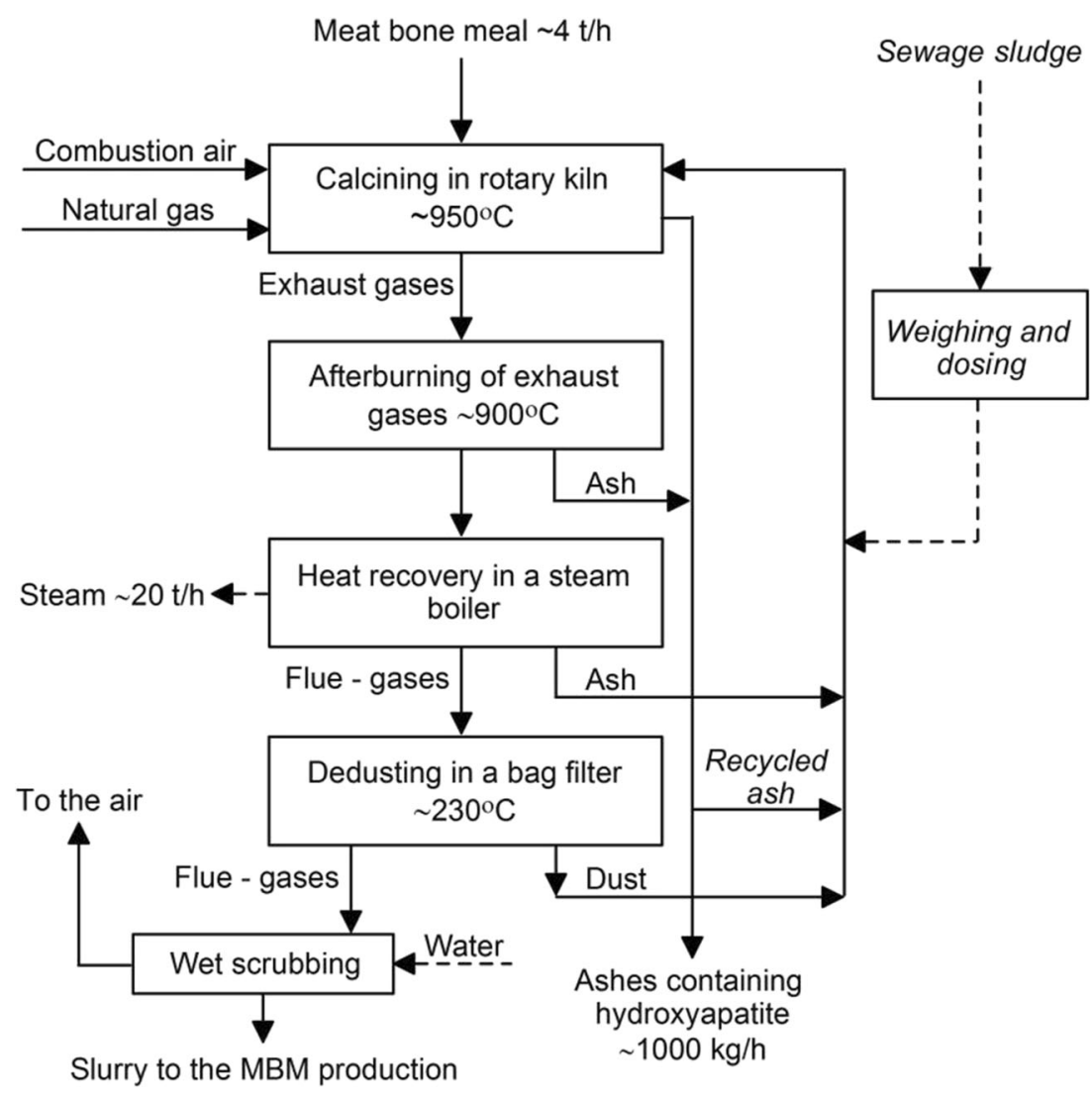


operations and reactions take place, including dryingdegassing, incineration and combustion of carbonised organic matter and calcining of calcium phosphates. MBM is dosed with screw conveyors into a co-current rotary kiln. The heat of combustion of MBM is estimated to be $18.5 \mathrm{MJ} / \mathrm{kg}$.

The ash is collected from the rotary kiln and after-burning chambers and transported by screw conveyors to the storage. The possibility is foreseen of recycling the ash into the rotary kiln and the weighing and dosing of the SS. The exhaust gas from the rotary kiln is additionally burned in the after-burning chamber. The heat of the exhaust gases is used to produce process steam in the boiler. Flue gas after the steam boiler is de-dusted in a bag filter, next cleaned using wet scrubbing and then directed to the air.

MBM and SS require calcining at temperatures up to $950{ }^{\circ} \mathrm{C}$. From the thermal decomposition of $1000 \mathrm{~kg}$ of MBM, $250 \mathrm{~kg}$ of ash was obtained, containing almost pure hydroxyapatite $\mathrm{Ca}_{5}\left(\mathrm{PO}_{4}\right)_{3} \mathrm{OH}$. The hydroxyapatite crystals obtained were well formed and not fused under these conditions. X-ray analysis also showed the presence of small amounts of $\mathrm{Ca}_{3}\left(\mathrm{PO}_{4}\right)_{2}, \mathrm{CaCO}_{3}, \mathrm{SiO}_{2}$ and $\mathrm{Fe}_{2} \mathrm{O}_{3}$ in the ash. The product contained 16-18\% $\mathrm{P}\left(36.6-41.2 \% \mathrm{P}_{2} \mathrm{O}_{5}\right)$ and on average $32.5 \% \mathrm{Ca}$. The phosphorus content in the product is therefore higher than in the compared phosphorites (see Table 1), where it is up to $33.8 \% \mathrm{P}_{2} \mathrm{O}_{5}$.

The heat of combustion of SSDM is $16.5 \mathrm{MJ} / \mathrm{kg}$, and ignition losses at $550{ }^{\circ} \mathrm{C}$ are $64 \%$. X-ray analysis showed that the basic crystalline phases of the ash from calcining of sewage sludge at $950{ }^{\circ} \mathrm{C}$ are quartz, anhydrite, iron calcium phosphate and haematite. There are also small amounts of $\mathrm{CaCO}_{3}$ and iron phosphate (Lynn et al. 2015; Tarko 2016).

Table 2 presents the contents of $\mathrm{P}_{2} \mathrm{O}_{5}$ and important impurities in the production of phosphoric acid and phosphorus fertilisers in meat-bone meal ash (MBMA) and sewage sludge ash (SSA).

MBM contains typically the following (\%): $8.0-10.0 \mathrm{CaO}$, 6.0-8.0 N, 0.5-0.6 $\mathrm{SiO}_{2}, 0.01-0.02 \mathrm{~F}, 0.5-1.0 \mathrm{~K}$ and $1.5-2.0$ $\mathrm{Na}$. The content of heavy metals ( $\mathrm{As}, \mathrm{Cu}, \mathrm{Pb}, \mathrm{Cr}, \mathrm{Ni}, \mathrm{Ag}$ ) is in range $0.001-0.0001 \%$ (Wilkosz-Jezzyk 2007). The results of the analysis indicate that MBMA has very high $\mathrm{P}_{2} \mathrm{O}_{5}$ content and is simultaneously a pure product containing very low amounts of iron and aluminium oxides (MER $<1$ ), heavy metals and fluorine. Thus, it is easier to produce phosphoric acid and phosphoric fertilisers from MBMA, in particular without the use of very troublesome defluorination operations in industrial practice.

SSDM contains typically of the following (\%): 3.5-4.0 $\mathrm{CaO}, 3.0-4.0 \mathrm{~N}, 8.0-10.0 \mathrm{SiO}_{2}$ and $0.15-0.3 \mathrm{~K}+\mathrm{Na}$. The content of heavy metals (As, $\mathrm{Cu}, \mathrm{Pb}, \mathrm{Cr}, \mathrm{Ni}, \mathrm{Ag}$ ) is in range $0.01-0.001 \%$. SSA has low $\mathrm{P}_{2} \mathrm{O}_{5}$ content and very high iron and aluminium oxide contents (MER > 200), and therefore, it is not used directly for the production of phosphoric acid. However, heavy metal content in SSDM is very low. From $1000 \mathrm{~kg}$ of SS dry mass, $280 \mathrm{~kg}$ of ash was obtained (Rzepecki 2003; Piasta and Lukawska 2016).

\section{Statistical analysis}

To obtain a high-quality phosphorus raw material comparable in quality to the best phosphorites used in the fertiliser industry, the co-combustion of MBM and SS would probably require a low addition of SS to MBM. For this reason, an analysis was carried out to determine the optimal mass proportions of MBM and SS for use in the co-combustion process.

Variables $\left(\mathrm{Fe}_{2} \mathrm{O}_{3}+\mathrm{Al}_{2} \mathrm{O}_{3}\right) / \mathrm{P}_{2} \mathrm{O}_{5}$ and MER were calculated using variables that determine the content of oxide forms in the tested materials, as a combination of them. Dependent variables were $\mathrm{P}_{2} \mathrm{O}_{5}, \mathrm{Fe}_{2} \mathrm{O}_{3}, \mathrm{Al}_{2} \mathrm{O}_{3}$ and $\mathrm{MgO}$ contents. Mass fractions of MBM and SS were independent variables.

The response surface regression method was used for mixtures. Response surface regression models for mixtures are similar to second-degree factor regression systems; however, they lack free expression. The regression equation for the regression model of the response surface for mixtures, with two continuous explanatory variables MBM and SSDM, has the form of Eq. 4:

$Y=b_{1} \mathrm{MBM}+b_{2} \mathrm{SSDM}$
Table 2 Content of $\mathrm{P}_{2} \mathrm{O}_{5}$ and basic impurities in MBM, MBMA, SSDM and SSA

\begin{tabular}{|c|c|c|c|c|c|c|c|c|}
\hline \multirow{2}{*}{$\begin{array}{l}\text { Phosphorite } \\
\text { type }\end{array}$} & \multicolumn{8}{|c|}{ Content $(\%)$ or ratio $(\%)$} \\
\hline & $\mathrm{P}_{2} \mathrm{O}_{5}$ & $\mathrm{Al}_{2} \mathrm{O}_{3}$ & $\mathrm{Fe}_{2} \mathrm{O}_{3}$ & $\begin{array}{l}\left(\mathrm{Fe}_{2} \mathrm{O}_{3}+\right. \\
\left.\mathrm{Al}_{2} \mathrm{O}_{3}\right) / \mathrm{P}_{2} \mathrm{O}_{5}\end{array}$ & $\mathrm{MgO}$ & $\mathrm{MER}^{\mathrm{a}}$ & $\begin{array}{l}\mathrm{Cd} \\
(\mathrm{ppm})\end{array}$ & $\begin{array}{l}X_{\mathrm{Cd}}(\mathrm{mg} \mathrm{Cd} / \mathrm{kg} \\
\left.\mathrm{P}_{2} \mathrm{O}_{5}\right)\end{array}$ \\
\hline MBM & 9.6 & 0.0 & 0.005 & 0.0005 & 0.13 & 1.405 & 0.002 & 0.02 \\
\hline MBMA & 41.0 & 0.0 & 0.014 & 0.0003 & 0.33 & 0.839 & 0.014 & 0.03 \\
\hline SSDM & 3.55 & 2.02 & 5.471 & 2.110 & 0.39 & 222.03 & 2.9 & 81.7 \\
\hline SSA & 12.8 & 7.28 & 19.70 & 2.110 & 1.40 & 222.03 & 10.44 & 81.7 \\
\hline
\end{tabular}

${ }^{\mathrm{a}}$ Minor element ratio, MER $=100 \times\left(\sum\left(\mathrm{Al}_{2} \mathrm{O}_{3}, \mathrm{Fe}_{2} \mathrm{O}_{3}, \mathrm{MgO}\right)\right) / \mathrm{P}_{2} \mathrm{O}_{5}(\%)$ 
Model coefficients were determined for each dependent variable. In order to select the most favourable variables of the dependent values, the utility function values of the independent variables were used, where a value of 1 means the most favourable and 0 unfavourable. All experimental planning was performed using STATISTICA (version 10.0) (Hill and Lewicki 2007; StatSoft 2006).

From the point of view of $\mathrm{Cd}$ content, hydroxyapatite ash is a very advantageous raw material for phosphorus fertiliser production. The European Commission has proposed a regulation of increasingly stringent limits of $\mathrm{Cd}$ in fertilisers. An initial limit of $60 \mathrm{mg} \mathrm{Cd} / \mathrm{kg}$ $\mathrm{P}_{2} \mathrm{O}_{5}$ will apply as soon as the regulation comes into force. A more stringent limit of $40 \mathrm{mg} \mathrm{Cd} / \mathrm{kg} \mathrm{P}_{2} \mathrm{O}_{5}$ will be phased in 3 years later, and the lowest limit of $20 \mathrm{mg} \mathrm{Cd} / \mathrm{kg} \mathrm{P}_{2} \mathrm{O}_{5}$ will come into force 9 years after the initial effective date (Regulation (EU) 2019). The Cd content in hydroxyapatite ash $X_{\mathrm{Cd}}=0.17 \mathrm{mg} \mathrm{Cd} / \mathrm{kg}$ $\mathrm{P}_{2} \mathrm{O}_{5}$ is much below of value for phosphate rock $\left(X_{\mathrm{Cd}}\right.$ ranged from 23 to $156 \mathrm{mg} \mathrm{Cd} / \mathrm{kg} \mathrm{P}_{2} \mathrm{O}_{5}$; see Table 3), so the two parameters of $\mathrm{Cd}(\mathrm{ppm})$ and $X_{\mathrm{Cd}}$ cannot be dependent variables.

\section{Results and discussion}

Statistical analysis allowed the assessment of the optimum composition of SS and MBM to be used in the cocombustion process in terms of quality parameters of the obtained ashes. Characteristic parameters of ashes after combustion of MBM and SS mixtures are shown in Table 3.

Model coefficients determined according to Eq. 4 were as follows: $\mathrm{Y}\left(\mathrm{P}_{2} \mathrm{O}_{5}\right) b_{1}-40.997 ; b_{2}-3.550 ; \mathrm{Y}\left(\mathrm{Al}_{2} \mathrm{O}_{3}\right) b_{1}-0$; $b_{2}-2.021 ; \mathrm{Y}\left(\mathrm{Fe}_{2} \mathrm{O}_{3}\right) b_{1}-0.143 ; b_{2}-5.471 ; \mathrm{Y}(\mathrm{MgO}) b_{1}-$ $0.332 ; b_{2}-1.017$. The results confirm the linear form of the models. To select most favourable variables with regard to the expected values (Table 1), utility function values of the independent variables were used, where a value of 1 means most favourable and 0 unfavourable. Examples of utility functions with a predictive model are shown in Fig. 2.

The analysis of co-combustion of MBM and SS mixtures was made in terms of assessing the quality of ashes obtained to compare their quality and the quality of phosphorites. Expected and approximated parameters of ashes (MBMA and SSA) from the combustion of their mixtures of are shown in Table 4. BPL value of these ashes could be considered to

Table 3 Characteristic parameters of MBM and SS co-combustion products

\begin{tabular}{|c|c|c|c|c|c|c|c|c|c|c|}
\hline \multirow[t]{2}{*}{ No } & \multicolumn{2}{|c|}{ Participation } & \multicolumn{8}{|c|}{ Characteristic parameters of ashes from combustion of MBM and SS mixtures } \\
\hline & MBM & SSDM & $\mathrm{P}_{2} \mathrm{O}_{5}(\%)$ & $\mathrm{Al}_{2} \mathrm{O}_{3}(\%)$ & $\mathrm{Fe}_{2} \mathrm{O}_{3}(\%)$ & $\left(\mathrm{Fe}_{2} \mathrm{O}_{3}+\mathrm{Al}_{2} \mathrm{O}_{3}\right) / \mathrm{P}_{2} \mathrm{O}_{5}$ & $\operatorname{MgO}(\%)$ & $\mathrm{MER}^{\mathrm{a}}$ & $\mathrm{Cd}(\mathrm{ppm})$ & $X_{\mathrm{Cd}}\left(\mathrm{mg} \mathrm{Cd} / \mathrm{kg} \mathrm{P}_{2} \mathrm{O}_{5}\right)$ \\
\hline 1 & 0 & 1 & 3.55 & 2.02 & 5.47 & 2.11 & 1.02 & 2.40 & 2.900 & 81.690 \\
\hline 2 & 0.05 & 0.95 & 5.42 & 1.92 & 5.21 & 1.31 & 0.98 & 1.50 & 2.756 & 50.821 \\
\hline 3 & 0.1 & 0.9 & 7.29 & 1.82 & 4.94 & 0.93 & 0.95 & 1.06 & 2.611 & 35.799 \\
\hline 4 & 0.15 & 0.85 & 9.17 & 1.72 & 4.67 & 0.70 & 0.91 & 0.80 & 2.467 & 26.913 \\
\hline 5 & 0.2 & 0.8 & 1.04 & 1.62 & 4.41 & 0.55 & 0.88 & 0.63 & 2.323 & 21.041 \\
\hline 6 & 0.25 & 0.75 & 1.91 & 1.52 & 4.14 & 0.44 & 0.85 & 0.50 & 2.179 & 16.872 \\
\hline 7 & 0.3 & 0.7 & 1.78 & 1.41 & 3.87 & 0.36 & 0.81 & 0.41 & 2.034 & 13.759 \\
\hline 8 & 0.35 & 0.65 & 1.66 & 1.31 & 3.61 & 0.30 & 0.78 & 0.34 & 1.890 & 11.346 \\
\hline 9 & 0.4 & 0.6 & 1.53 & 1.21 & 3.34 & 0.25 & 0.74 & 0.29 & 1.746 & 9.21 \\
\hline 10 & 0.45 & 0.55 & 2.40 & 1.11 & 3.07 & 0.21 & 0.71 & 0.24 & 1.601 & 7.849 \\
\hline 11 & 0.5 & 0.5 & 2.27 & 1.01 & 2.81 & 0.17 & 0.67 & 0.20 & 1.457 & 6.541 \\
\hline 12 & 0.55 & 0.45 & 2.15 & 0.91 & 2.54 & 0.14 & 0.64 & 0.17 & 1.313 & 5.437 \\
\hline 13 & 0.6 & 0.4 & 2.02 & 0.81 & 2.27 & 0.12 & 0.61 & 0.14 & 1.168 & 4.491 \\
\hline 14 & 0.65 & 0.35 & 2.89 & 0.71 & 2.01 & 0.10 & 0.57 & 0.12 & 1.024 & 3.672 \\
\hline 15 & 0.7 & 0.3 & 29.76 & 0.61 & 1.74 & 0.08 & 0.54 & 0.10 & 0.880 & 2.956 \\
\hline 16 & 0.75 & 0.25 & 31.64 & 0.51 & 1.48 & 0.06 & 0.50 & 0.08 & 0.736 & 2.325 \\
\hline 17 & 0.8 & 0.2 & 33.51 & 0.40 & 1.21 & 0.05 & 0.47 & 0.06 & 0.591 & 1.764 \\
\hline 18 & 0.85 & 0.15 & 35.38 & 0.30 & 0.94 & 0.04 & 0.43 & 0.05 & 0.447 & 1.263 \\
\hline 19 & 0.9 & 0.1 & 37.25 & 0.20 & 0.68 & 0.02 & 0.40 & 0.03 & 0.303 & 0.812 \\
\hline 20 & 0.95 & 0.05 & 39.12 & 0.10 & 0.41 & 0.01 & 0.37 & 0.02 & 0.158 & 0.405 \\
\hline 21 & 1 & 0 & 41.00 & 0.00 & 0.14 & 0.0034 & 0.33 & 0.01 & 0.014 & 0.034 \\
\hline
\end{tabular}

${ }^{\mathrm{a}}$ Minor element ratio, $\mathrm{MER}=100 \times\left(\sum\left(\mathrm{Al}_{2} \mathrm{O}_{3}, \mathrm{Fe}_{2} \mathrm{O}_{3}, \mathrm{MgO}\right)\right) / \mathrm{P}_{2} \mathrm{O}_{5}(\%)$ 
a)
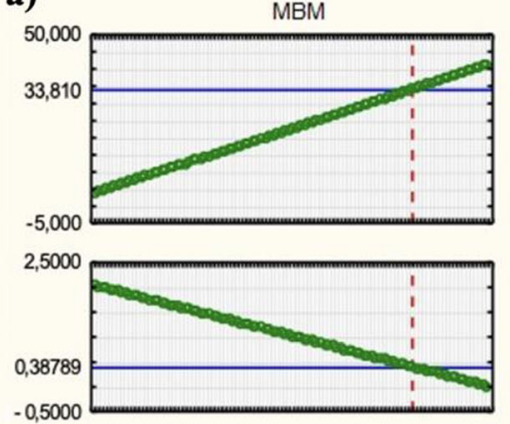

7,000
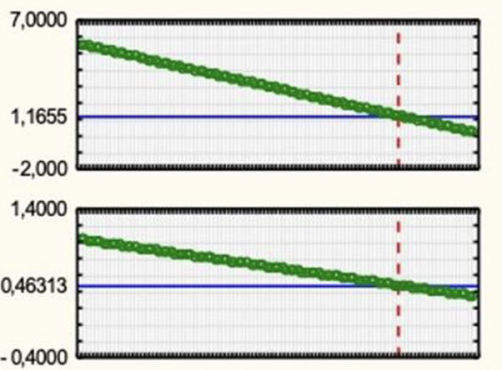

$-0,4000$

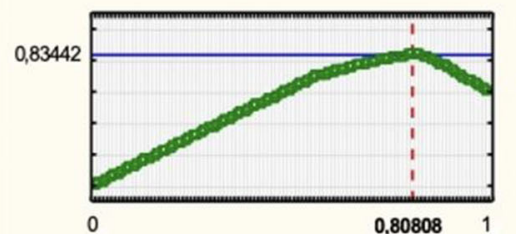

$0,80808 \quad 1$

b)
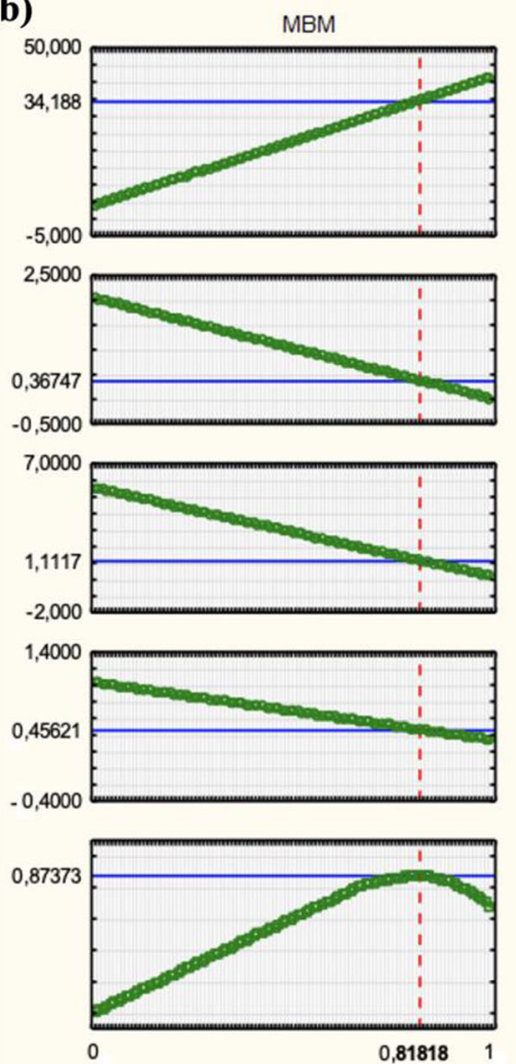
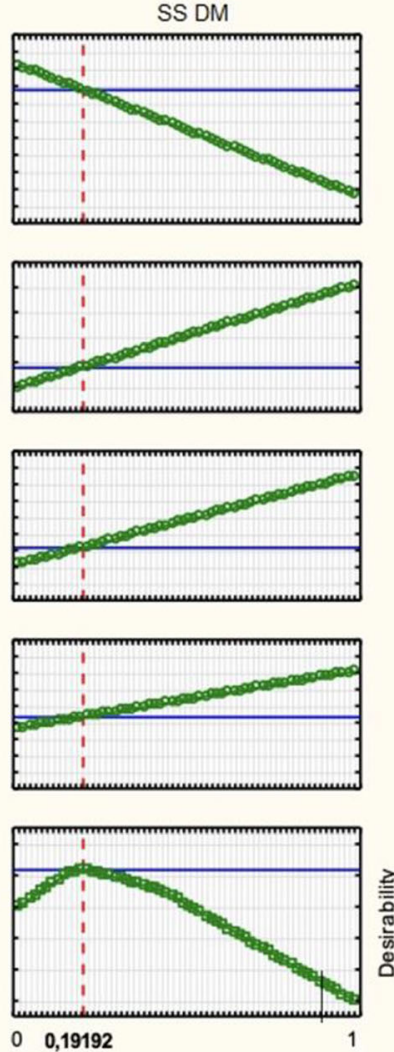

SS DM
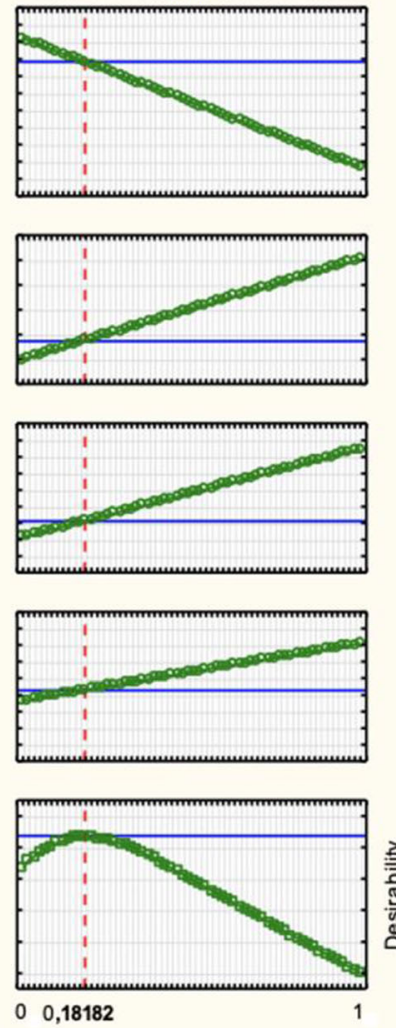

Desirability
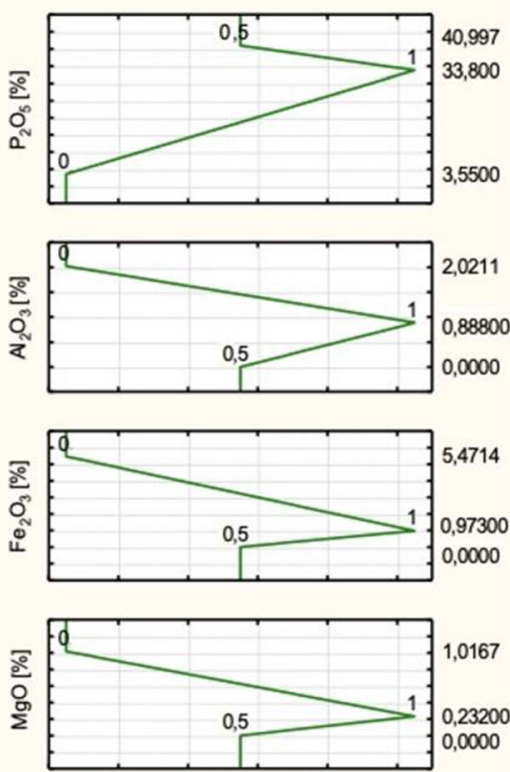

高
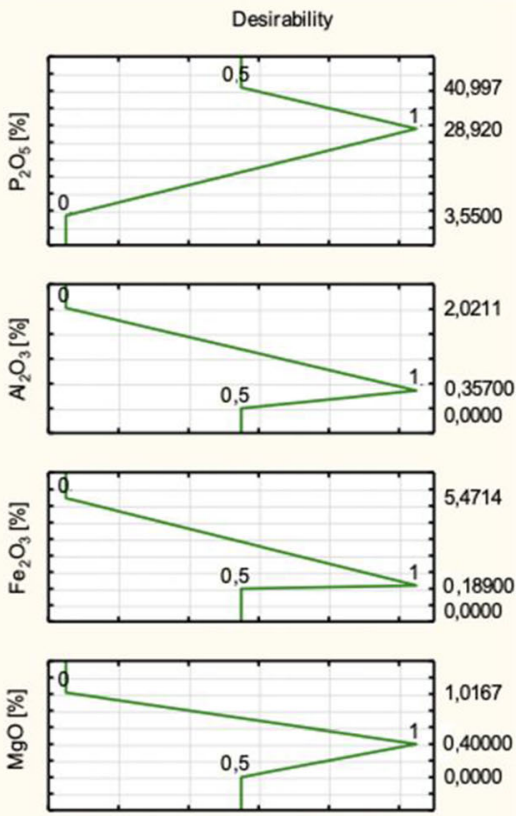

Fig. 2 The utility function with the predictive model. a Morocco-Togo. b Tunisia-Syria. c Senegal LamLam 
c)

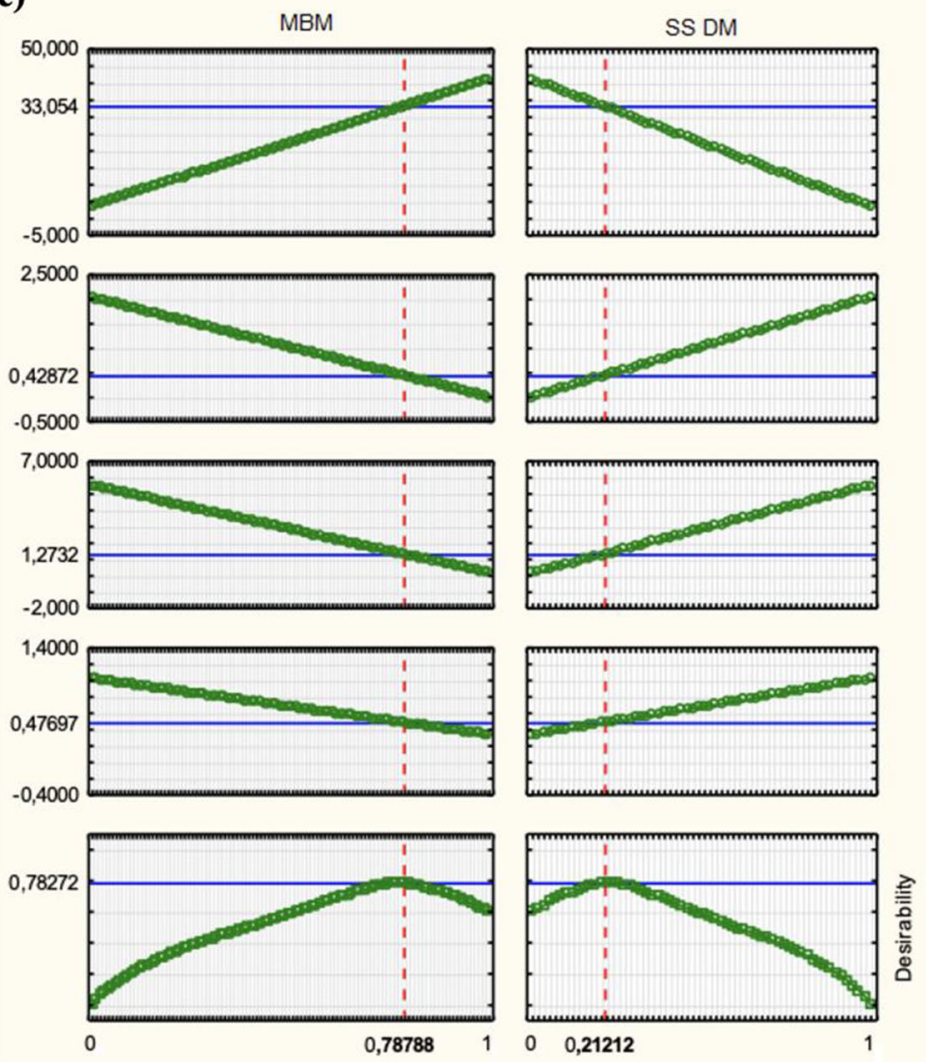

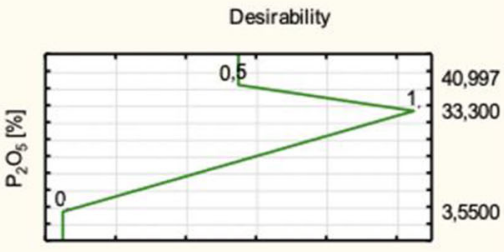
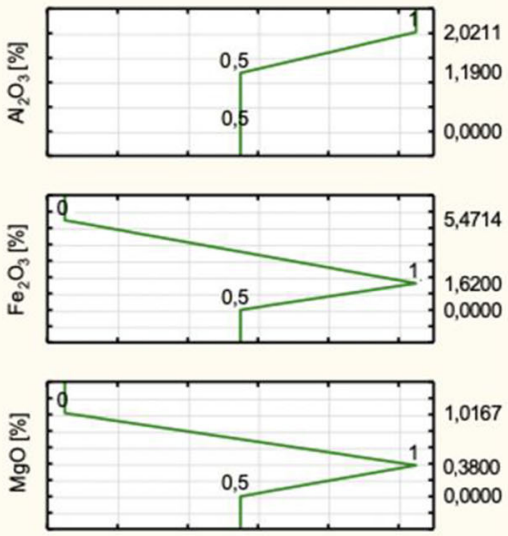

Fig. 2 (continued)

represent a high-quality material, with BPL in the range 71-76 (only one value of 66).

Levels of impurities $\left(\mathrm{Fe}_{2} \mathrm{O}_{3}+\mathrm{Al}_{2} \mathrm{O}_{3}\right) / \mathrm{P}_{2} \mathrm{O}_{5}$ in phosphorites were in the range $0.01-0.08$ (only one value of 0.16 ) and in MBMA and SSA mixtures in the range 0.04-0.08. The acceptable level of impurities in $\mathrm{H}_{3} \mathrm{PO}_{4}$ used to produce fertilisers is 0.02-0.08 (Podolak 2017). MER values for phosphorites were in the range 3.0-16.8 and for MBMA and SSA mixtures in the range 5.4-9.4.

\section{Environmental and economic effect of the co- combustion of MBM and SS mixtures}

An actually developed MBM combustion project realised by the Farmutil Company (Kowalski and Makara 2017) assumes a combustion of 30,000 t/year of MBM and the production of $7500 \mathrm{t} / \mathrm{year}$ of ash containing hydroxyapatite. As mentioned, $250 \mathrm{~kg}$ of ash was obtained from $1 \mathrm{t}$ of combusted MBM and $280 \mathrm{~kg}$ of ash from $1 \mathrm{t}$ of combusted SSDM.

The quality parameters of ash from the co-combustion of MBM and SS were calculated for two variants assuming the co-combustion of a mixture of $1000 \mathrm{~kg}$ MBM and $269 \mathrm{~kg}$ SSDM (variant I) or $1000 \mathrm{~kg}$ MBM and $83 \mathrm{~kg}$ SSDM (variant II). Variant I value resulted from the last line of Table 4. This is proportion allowing to obtain ash containing 21.2\% SSDM, comparable with phosphorite Senegal LamLam. Variant II value resulted from a total of $2500 \mathrm{t}$ /year SSDM of SS produced by the company (Kowalski and Makara 2017). The co-combustion of a mixture of 30,000 t/year MBM and 2499 t/year SS could allow the utilisation of all the SS produced by the company per year.

In variant I for the capacity of combustion mixture of 30,000 t/year MBM and 8070 t/year SSDM could be produced $9870 \mathrm{t}$ /year of hydroxyapatite ash qualitatively comparable with phosphorite Senegal LamLam characterised with BPL-72; $\left(\mathrm{Fe}_{2} \mathrm{O}_{3}+\mathrm{Al}_{2} \mathrm{O}_{3}\right) / \mathrm{P}_{2} \mathrm{O}_{5}-0.05 ;$ and MER-6.60.

In proposed for implementation in Farmutil variant II, for the capacity of combustion mixture of 30,000 t/year MBM and $2.499 \mathrm{t} /$ year SSDM could be produced $8200 \mathrm{t} /$ year of very high-quality ash characterised with BPL-83; $\left(\mathrm{Fe}_{2} \mathrm{O}_{3}+\right.$ $\left.\mathrm{Al}_{2} \mathrm{O}_{3}\right) / \mathrm{P}_{2} \mathrm{O}_{5}-0.04$; and MER-2.85.

The environmental effect is the substitution of $8200 t$ of phosphorites used for the production of phosphoric fertilisers with ashes from the co-combustion of a mixture of MBM and SS. Ultimately, this amount may increase to over 27,000 tif the amount of thermal MBM utilisation increases to 100,000 t/year. The proposed method also allows the utilisation of all the SS obtained in Farmutil, an amount of 2500 t/year SSDM after biological treatment of wastewater from MBM and municipal production. 


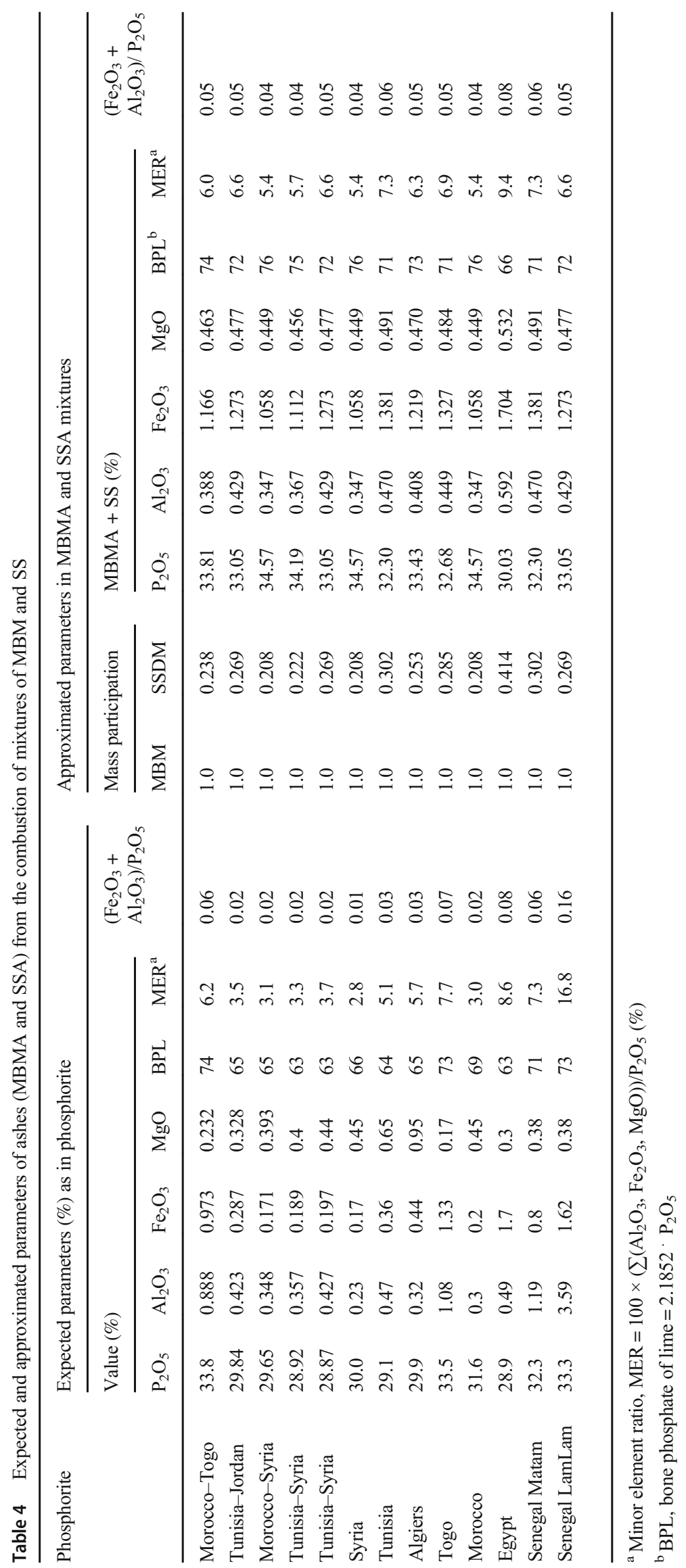


The high-quality ashes (Kowalski and Makara 2017) do not contain fluorine compounds, and during their processing into phosphoric acid, there is no need for a complicated phosphorite de-fluorination stage. Cadmium content is also at trace levels. The ashes also do not contain radioactive compounds, which are present in trace amounts in all phosphates. For example, Senegal phosphorite contains $101 \mathrm{ppm}_{3} \mathrm{O}_{8}$ (BAT 2000).

The co-combustion of MBM and SS is an example of a production complex using cleaner technologies and the incorporation of a number of elements included in the principles of a circular economy $\mathrm{CE}$ on a microeconomic scale. The analysed CE concept is based on the use of cleaner production $\mathrm{CP}$ activities such as the recycling (in- and off-process) of substrates used for combustion, the substitution of natural phosphorites in the production of phosphorus compounds by ash and its use for technological purposes (Stokłosa et al. 2019; Kowalski and Krupa-Żuczek 2007).

The economic effects of selling ash from MBM and SS mixtures are also significant. A developed capacity of $8200 \mathrm{t} /$ year of ashes amounts to 1.033 million USD and a target capacity of 27,330 t/year ashes to 3.443 million USD. The price adopted for the calculation corresponds to the current price of phosphorites on the Polish market of $126 \mathrm{USD} / \mathrm{t}$ phosphorites, loco Polish harbour (based on Money.pl). There are at least four potential recipients of this product on the Polish market.

\section{Conclusions}

Based on the results, the following conclusions can be drawn:

(1) The optimal mass proportions of co-combusted MBM and SS to obtain ash with a quality comparable or better than that of phosphorites used for the production of phosphoric acid were determined. Maximum SSDM/MBM ratio to 0.269 allowed obtaining ashes, considered to be a high-quality phosphate raw material with average $\mathrm{BPL}$ value of 72.0 , level of impurities $\left(\mathrm{Fe}_{2} \mathrm{O}_{3}+\mathrm{Al}_{2} \mathrm{O}_{3}\right) / \mathrm{P}_{2} \mathrm{O}_{5}$ of 0.05 and MER of 6.6 .

(2) In the case of the developed project analysed, the goal was the co-combustion of a mixture of 30,000 t/year MBM and 2499 t/year SS, which would allow the use of all the SS produced by Farmutil Co. The very highquality ash obtained had a BPL value 83 , a level of impurities $\left(\mathrm{Fe}_{2} \mathrm{O}_{3}+\mathrm{Al}_{2} \mathrm{O}_{3}\right) / \mathrm{P}_{2} \mathrm{O}_{5}$ of 0.04 and an MER value of 2.85 .

Authors' contributions Conceptualisation: Zygmunt Kowalski; formal analysis: Zygmunt Kowalski, Marcin Banach; investigation: Zygmunt Kowalski, Agnieszka Makara; methodology: Zygmunt Kowalski, Marcin Banach; visualisation: Zygmunt Kowalski, Marcin Banach, Agnieszka Makara; writing — original draft: Zygmunt Kowalski.
Data availability All data generated or analysed during this study are included in this published article.

\section{Compliance with ethical standards}

Ethics approval and consent to participate Not applicable.

Consent for publication Not applicable.

Competing interests The authors declare that they have no competing interests.

Open Access This article is licensed under a Creative Commons Attribution 4.0 International License, which permits use, sharing, adaptation, distribution and reproduction in any medium or format, as long as you give appropriate credit to the original author(s) and the source, provide a link to the Creative Commons licence, and indicate if changes were made. The images or other third party material in this article are included in the article's Creative Commons licence, unless indicated otherwise in a credit line to the material. If material is not included in the article's Creative Commons licence and your intended use is not permitted by statutory regulation or exceeds the permitted use, you will need to obtain permission directly from the copyright holder. To view a copy of this licence, visit http://creativecommons.org/licenses/by/4.0/.

\section{References}

Asif F, Lieder M, Rashid A (2016) Multi-method simulation based tool to evaluate economic and environmental performance of circular product systems. J Clean Prod 139:1261-1281. https://doi.org/10.1016/j. jclepro.2016.08.122

BAT Best Available Techniques for Pollution Prevention and Control in the European Fertilizer Industry. Production of Phosphoric Acid (2000) Booklet No. 4 of 8. EFMA European Fertilizer Manufacturers Association, Ave. E van Nieuwenhuyse 4, B-1160 Brussels, Belgium. http://productstewardship.eu/fileadmin/user upload/user_upload_prodstew/documents/Booklet_nr_4 Production_of_Phosphoric_Acid.pdf. Accessed 12 January $20 \overline{2} 0$

Becker P (1989) Phosphates and phosphoric acid. Marcel Dekker, Inc., New York

Bertanza G, Baroni P, Canato M (2016) Ranking sewage sludge management strategies by means of decision support systems: a case study. Resour Conserv Recycl 110:1-15. https://doi.org/10.1016/j. resconrec.2016.03.011

Bilitewsky B (2012) The circular economy and its risks. Waste Manag 32:1-2. https://doi.org/10.1016/j.wasman.2011.10.004

Blatt H, Tracy RJ (1996) Petrology. Igneous, sedimentary, and metamorphic. Freeman WH, New York

Cascarosa E, Gea G, Arauzo J (2012) Thermochemical processing of meat and bone meal: a review. Renew Sust Energ Rev 16:942957. https://doi.org/10.1016/j.rser.2011.09.015

Černý J, Balík J, Kulhánek M, Vašák F, Peklová L, Sedlář O (2012) The effect of mineral $\mathrm{N}$ fertiliser and sewage sludge on yield and nitrogen efficiency of silage maize. Plant Soil Environ 58:76-83. https:// doi.org/10.17221/538/2011-PSE

Conesa JA, Fullana A, Font R (2003) Thermal decomposition of meat and bone meal. J Anal Appl Pyrolysis 70:619-630. https://doi.org/ 10.1016/S0165-2370(03)00044-5

Coutand M, Cyr M, Deydier E, Guilet R, Clastres P (2008) Characteristics of industrial and laboratory meat and bone meal 
ashes and their potential applications. J Hazard Mater 150:522-532. https://doi.org/10.1016/j.jhazmat.2007.04.133

Filippelli GM (2011) Phosphate rock formation and marine phosphorus geochemistry: the deep time perspective. Chemosphere 84:759 766. https://doi.org/10.1016/j.chemosphere.2011.02.019

Fryda L, Panopoulos K, Vourliotis P, Pavlidou E, Kakaras E (2006) Experimental investigation of fluidised bed co-combustion of meat and bone meal with coals and olive bagasse. Fuel 85:1685-1699. https://doi.org/10.1016/j.fuel.2006.01.020

Ghisellini P, Cialani C, Ulgiati SA (2016) A review on circular economy: the expected transition to a balanced interplay of environmental and economic systems. J Clean Prod 114:11-32. https://doi.org/10. 1016/j.jclepro.2015.09.007

Gulyurtlu I, Boavida D, Abelha P, Lopes MH, Cabrita I (2005) Cocombustion of coal and meat and bone meal. Fuel 84:2137-2148. https://doi.org/10.1016/j.fuel.2005.04.024

Heikkinen JM, Venneker BCH, di Niola G, de Jong W, Spliethoff H (2008) CFD simulation and experimental validation of cocombustion of chicken litter and MBM with pulverized coal in a flow reactor. Fuel Process Technol 89:874-889. https://doi.org/10. 1016/j.fuproc.2008.02.004

Hill T, Lewicki P (2007) Statistics: methods and applications. StatSoft, Inc

Hiromi Ariyaratne WK, Malagalage A, Melaaen MC, Tokheim LA (2015) CFD modeling of meat and bone meal (MBM) in a cement rotary kiln. Int J Model Optim 5:353-360. https://doi.org/10.7763/ IJMO.2015.V5.488

Hogan CM (2011) Phosphate. Encyclopedia of Earth. National Council for Science and the Environment, Washington DC

Hu S, Jia F, Marinescu C, Cimpoesu F, Qi Y, Tao Y, Stroppa A, Ren W (2017) Ferroelectric polarization of hydroxyapatite from density functional theory. RSC Adv 7:21375-21379. https://doi.org/10. 1039/C7RA01900A

International Fertilizer Development Center (1998) United Nations development organization. Fertilizer Manual, Kluver Academic Publishers, The Netherlands

Kowalski Z, Banach M, Staroń P, Makara A (2012) Granulation of meat and bone meal, straw and sewage sludge. Przem Chem 91(5):805810 (in Polish)

Kowalski Z, Krupa-Żuczek K (2007) A model of the meat waste management. Pol J Chem Technol 9:91-97. https://doi.org/10.2478/ v10026-007-0098-4

Kowalski Z, Makara A (2017) Technological concept meat and bonemeal MBM combustion unit for Farmutil S.a. Cracow University of Technology (unpublished work) (in Polish)

Lucid JD, Fenton O, Healy MG (2013) Estimation of maximum biosolids and meat and bone meal application to a low P index soil and a method to test for nutrient and metal losses. Water Air Soil Pollut 224:1464-1475. https://doi.org/10.1007/s11270-013-1464-x

Lynn CJ, Dhir RK, Ghataora GS, West RP (2015) Sewage sludge ash characteristics and potential for use in concrete. Constr Build Mater 98:767-779. https://doi.org/10.1016/j.conbuildmat.2015.08.122

Morais J, Barbosa R, Lapa N, Mendes B, Gulyurtlu I (2011) Environmental and socio-economic assessment of co-combustion of coal, biomass and non-hazardous wastes in a power plant. Resour Conserv Recycl 55:1109-1118. https://doi.org/10.1016/j. resconrec.2011.06.011

Möller K (2015) Assessment of alternative phosphorus fertilizers for organic farming: meat and bone meal. Improve, Fact Sheet:1-8 https://orgprints.org/29505/1/moeller2015-factsheet-Meat-andbone-meal.pdf
Zapata F, Roy RN (2004) Use of phosphate rocks for sustainable agriculture. FAO fertilizer and plant nutrition bulletin, no. 13. http://www. fao.org/docrep/007/y5053e/y5053e06.htm

Nogalska A, Zalewska M (2013) The effect of meat and bone meal on phosphorus concentrations in soil and crop plants. Plant Soil Environ 59:575-580. https://doi.org/10.17221/594/2013-PSE

Piasta W, Lukawska M (2016) The effect of sewage sludge ash on properties of cement composites. Procedia Eng 161:1018-1024. https:// doi.org/10.1016/j.proeng.2016.08.842

Podolak A (2017) The research on influence of physicochemical properties of wet phosphoric acid on the process of acquiring phosphoric salts. West Pomeranian University of Technology, Dissertation (in Polish)

Raheem A, Sikarwar VS, He J, Dastyar W, Dionysiou DD, Wang W, Zhao M (2018) Opportunities and challenges in sustainable treatment and resource reuse of sewage sludge: a review. Chem Eng J 337:616-641. https://doi.org/10.1016/j.cej.2017.12.149

Regulation (EU) 2019/1009 of the European Parliament and of the Council of 5 June 2019 laying down rules on the making available on the market of EU fertilising products and amending Regulations (EC) No 1069/2009 and (EC) No 1107/2009 and repealing Regulation (EC) No 2003/2003. https://eur-lex.europa.eu/legalcontent/EN/TXT/PDF/?uri=CELEX:32019R1009.

Rzepecki T (2003) Research on the utilization of wastes from the municipal wastewater treatment process and recovery of phosphorus compounds from them. Dissertation, Cracow University of Technology (in Polish)

Staron P, Kowalski Z, Staron A, Banach M (2015) Thermal processing of feather and meat-bone meal mixtures. Przem Chem 94(5):806-809 (in Polish)

Staroń P, Kowalski Z, Staroń A, Banach M (2017) Thermal treatment of waste from the meat industry in high scale rotary kiln. Int J Environ Sci Technol 14:1157-1168. https://doi.org/10.1007/s13762-0161223-9

Staroń P, Kowalski Z, Staroń A, Banach M (2017a) Thermal conversion of granules from feathers, meat and bone meal and poultry litter to ash with fertilizing properties. Agric Food Sci 26:173-180. https:// doi.org/10.23986/afsci.59561

StatSoft (2006) Electronic statistics handbook PL. Krakow, WEB http:// www.statsoft.pl/textbook/stathome.html, (in Polish)

Stokłosa H, Andryszak P, Kowalski Z, Makara A (2017) Method of thermal utilization of meat and bone meal. Polish Patent Application P.422538 (in Polish)

Stokłosa H, Kowalski Z, Makara A (2019) The use of circular economy model and cleaner technologies on the example of the polish agrofood company Farmutil. Przem Chem 98(5):709-714 (in Polish)

Tarko B (2016) Phosphorus recovery from the mineral residues after sewage sludge thermal utilization process. Cracow University of Technology, Dissertation (in Polish)

Wilkosz-Język A (2007) Production of calcium phosphate from meat and bone meal. Cracow University of Technology, Dissertation (in Polish)

Wzorek M (2015) Characterization of physical and chemical properties of fuel containing animal waste. Waste to Energy WIT Transactions on State of the Art in Science and Engineering 84:55-65

Publisher's note Springer Nature remains neutral with regard to jurisdictional claims in published maps and institutional affiliations. 